\title{
EFFECT OF MIXED PROTEIN SCHEDULES ON NILE TILAPIA (OREOCHROMIS NILOTICUS) PERFORMANCE IN COMBINATION WITH SOME FEED ADDITIVES I-MIXED PROTEIN SCHEDULES AND SODIUM CHLORIDE
}

\section{Osama M. El-Husseiny ; Galal ElDin M. Abdul-Aziz and Rania S. Mabroke \\ Animal Production Department., Faculty of Agriculture Cairo Univerity}

Key words: Nile Tilapia, protein, $\mathrm{NaCl}, \mathrm{Na} / \mathrm{K}$ ratio, feed additives

\section{ABSTRACT}

T he experiment was designed in a $(4 \times 3)$ factorial arrangement of treatments to investigate the effect of four different mixed protein schedules and three dietary $\mathrm{Na} / \mathrm{K}$ ratios on Nile tilapia performance. The four protein schedules were achieved by alternating the diet (A ; $31 \% \mathrm{CP}$ ) and diet $(\mathrm{B} ; 24 \% \mathrm{CP})$ as follows (6-days- $\mathrm{A})$,(5days- $\mathrm{A} / 1$ day- $\mathrm{B})$, (4days-A /2days-B) and (3days-A /3days-B).Meanwhile, sodium chloride was added to study the effect of $\mathrm{Na} / \mathrm{K}$ ratio of $0.5,1.5$ and 2 on utilization of dietary protein, amylase and lipase activity and serum thyroid hormone level. Moreover, the interaction between mixed protein schedules and $\mathrm{Na} / \mathrm{K}$ ratio has been investigated. The results are summarized as follows:

- The optimal protein schedule for tilapia performance was either $(5 \mathrm{~A} / 1 \mathrm{~B})$ or $(4 \mathrm{~A} / 2 \mathrm{~B})$.

- Fish in $(5 \mathrm{~A} / 1 \mathrm{~B})$ or $(4 \mathrm{~A} / 2 \mathrm{~B})$ schedules utilized protein more efficiently than fish fed on higher protein diet continuously (6A):

- Addition of $\mathrm{NaCl}$ to fish diet to achieve $\mathrm{Na} / \mathrm{k}$ ratio 2 was beneficial and improved fish performance with decreasing inclusion of higher protein diet in protein schedule (3A/3B)

- Increasing $\mathrm{Na} / \mathrm{K}$ ratio decreased thyroid hormone level in the male and maintained it in contrast with the female

- Raising of $\mathrm{Na} / \mathrm{K}$ up to 2 decreased lipase activity and ether extract digestibility.

- The lowest feeing cost was recorded for fish fed on on diets with $\mathrm{Na} / \mathrm{K}$ ratio 2 and fed on on (4A/2B) schedule. 


\section{INTRODUCTION}

Nile tilapia is a freshwater fish native to Africa and Middle East region. The relative ease of culture of tilapia and its rapid growth rate under tropical and semi-topical climates have led to its widespread distribution. Such advantages have given tilapia an important value over other species. China is by far the largest producer of farmed Nile tilapia where the annual Chinese production had risen to nearly $806000 t$ followed by Egypt which reported a production of nearly $200000 t$ (FAO, 2003).

As fishes are usually stocked in earthen ponds at high densities, a nutritionally complete and economically viable diet is critical to the success of a commercial operation. Protein is the major organic material in fish tissue, making up about $65 \%$ to $75 \%$ of the total body content on a dry-weight basis (Avault, 1996) and it is the most expensive component of the diet. Several experiments have been carried out to determine the optimal dietary protein level for Nile tilapia (Oreochromis niloticus). These experiments came out with different results, and the range of optimal dietary protein level laied between 25-35\% (Wang et al.,1985; Santiago.,1985; Siddiqui et al.,1988; Abdelghany,2000) for fish size $(9-40 \mathrm{~g})$.

The cost of feed may be reduced by improving the utilization of protein via proper feeding strategies (Sehagal and Toor, 1991) or by supplementing diets with some feed additives. De Silva (1985) found that fish fed on on diets with different protein leveis (mixed protein schedule) were better than those with a constant recommended protein level. The potential of mixed protein schedules in reducing feed costs and/or improving nutrient utilization has also been pointed out for species such as Channa striata (Hashim,1994), Labeo rohita (Saha and Ray, 1998), Indian major carp (Nandeesha et al., 1994), common carp (Cyprinus carpio) under pond culture systems (Nandeesha et al., 1995), and trout(Oncorhynchus Mykiss) (Sevgili et al.,2006).

Sodium and potassium are the most essential minerals in animal life because of their role in electrolyte and acid base balance. Sodium is the principal extracellular cation, whereas potassium is the principal intracellular cation in animal tissues. Freshwater-fish take up salt from the surrounding water through active transport to maintain their osmotic balance (Shiau and $\mathrm{Lu}, 2004$ ), a process that consumes about $25 \%-50 \%$ of the total metabolic energy output (Laiz-Carrion et al., 2002). Sodium 
chloride could be helpful in reducing the energy utilized for this purpose, and more energy could be channeled into growth (Keshavanath et al.,2003). Meanwhile, the gradient of $\mathrm{K}$ and $\mathrm{Na}$ over the cell's plasma membrane is maintained by $\mathrm{Na}-\mathrm{K}$ ATPase activity. Excess of one cation to the other can change the efficiency of the Na-K pump. So, it was supposed that an optimal dietary $\mathrm{Na} / \mathrm{K}$ ratio might reduce the energy requirement to maintain this gradient. (Fig.1).

Dersjant-Li et al.(2001)concluded that growth, nutrient utilization efficiency, body dry matter, fat, nitrogen and energy content of African catfish increased in a linear or quadratic manner with increasing dietary: $\mathrm{Na} / \mathrm{K}$ ratios between 0.2 and 2.5 . Several studies on mammals proved the influence of the food ingredients on the digestive enzyme activity (Grewal and Mahmood, 2004). In recent studies carried out on a number of adult fish species, the effects of food manipulations on the digestive enzymes activity were demonstrated (Harpaz et al., 2005a,b). Meanwhile, Peter et al. (2000) suggested that thyroid hormones may have a role in ion uptake in Mozambique tilapia. Thyroid hormones play at least a supportive role in seawater acclimation (Mccormick, 2001). Therefore, it was supposed that elevating $\mathrm{Na} / \mathrm{K}$ ratio may influence digestive enzymes activity and serum thyroid hormone.

The experiment was designed to investigate the effect of mixed protein schedules using diet $(\mathrm{A})(31 \% \mathrm{CP}$; according to tilapia requirement $\mathrm{NRC}, 1993)$ and $\operatorname{diet}(\mathrm{B})(24 \% \mathrm{CP}$; according to tilapia minimum balanced amino acid requirement NRC,1993)on tilapia performance. Meanwhile, the effect of sodium chloride addition which change $\mathrm{Na} / \mathrm{K}$ ratio on feed utilization was studied. Moreover, the interaction between mixed protein schedules and $\mathrm{Na} / \mathrm{K}$ ratio was examined.

\section{MATERIALS AND METHODS}

\section{Experiment design:}

This experiment was carried out in fish laboratory of Animal and Poultry Nutrition Department, Faculty of Agriculture, Cairo University to study the effects of four mixed protein schedules ( 6 days- $A),(5$ days-A / 1 day- $B),(4$ days-A $/ 2$ days $B)$, and $(3$ days- $A / 3$ days-B), and $\mathrm{Na} / \mathrm{K}$ ratio $(0.5,1.5$ and 2 ) on improving protein utilization of Nile tilapia (Table 1).Mixed protein schedule was repeated each 6 days for 90 days. The experiment consisted of 12 replicate treatments, the apparently healthy experimental fish (Oreochromis 
Osama M. El-Husseiny et al.

niloticus) were carefully transferred to the laboratory to be acclimatized for one week. Fishes with average initial body weight of $14-15 \mathrm{~g}$ were stocked in glass aquaria $(80 \mathrm{~cm} \times 50 \mathrm{~cm} \times 40 \mathrm{~cm})$ at a density of 12 fish in each aquarium $(1.4 \mathrm{~g} / \mathrm{L})$. Dechlorinated tap water was used .Water was changed three times a week. The aquaria were aerated by air pump to supply the needed oxygen. $\mathrm{Na} / \mathrm{K}$ ratio in diets $\mathrm{A}(31 \% \mathrm{CP}$; according to tilapia requirement $\mathrm{NRC}, 1993)$ and $\mathrm{B}(24 \% \mathrm{CP}$; according to tilapia minimum balance amino acid requirement $N R C, 1993)$ was $0.5 \%$, and the ratio was raised up to 1.5 (diets $A_{1.5}$ and ${ }_{B 1.5}$ ) and 2 (diets $A_{2}$ and $B_{2}$ ) by supplementation with sodium chloride at $4 \%$ and $8 \%$ levels, respectively, while the potassium content was constant.

Experimental diets and feeding practice

The ingredients and proximate composition of diets are presented in Table (2). After the ingredients have been perfectly mixed, cold water was added with continuous stirring until the mixture became suitable for making granules. The wet mixture was passed through granule machine. The produced pellets were dried at room temperature for three days then packed in plastic bags. Fishes were fed on at $3 \%$ of live body weight, and were weighed once every 2 weeks to adjust daily ration, accordingly.

\section{Experimental parameters:}

1) Average daily gain $(A D G)=$ (final body weight- initial body weight)/ time(days).

2) Feed conversion ratio(FER) = feed intake (g)/ weight gain (g).

3) Protein efficiency ratio(PER) =body weight gain (g)/rotein intake (g).

4) Protein productive value $(P P V)=$ [protein gain $(\mathrm{g}) /$ protein intake $(\mathrm{g})$ ] $\mathrm{x} 100$.

5)Energy retention(ER) $=[$ (body Energy gain(kcal) /energy intake(kcal)] x 100,(Hepher, 1988)

\section{Sample preparation for chemical analysis}

Experimental diets, fish samples and faeces were analyzed for proximate composition according to AOAC (1990). Three fish from each aquarium of experimental treatments were taken for chemical analysis of body composition. Sampled fish were sacrificed and frozen soon afterward at a temperature of $-20^{\circ} \mathrm{C}$. To obtain a homogenous material, fish were dried at $60-70^{\circ} \mathrm{C}$ overnight to determine dry matter content (DM). The crude protein (CP) was determined by micro kjeledahel method (Nx6.25). Ether extract (EE) was determined in soxhelt apparatus using petrolium ether $\left(60-80^{\circ} \mathrm{C}\right)$. Ash content was determined in the 
muffle furnace at $550^{\circ} \mathrm{C}$ for 3 hours. Sodium and potassium in diet and fish carcass were determined in ash extract solution by the atomic absorption device. The gross energy content ( $\mathrm{kcal} \mathrm{GE} / \mathrm{g}$ ) in feed faeces and fish carcass was calculated using factors $5.65,4.20$ and $9.45 \mathrm{kcal} / \mathrm{g}$ for protein, carbohydrate and lipid, respectively, according to Hepher et al. (1983).

\section{Determination of amylase and lipase activity}

At the end of the experiment, two fish from each aquarium of experimental treatments were sacrificed and then stomachs were separated, and prepared for amylase and lipase enzymes determination according to Bernfeld (1955) and Mia et al.(1978) respectively.

\section{Digestion Trials}

At the end of the experiment, digestion trials were conducted in glass aquaria to determine digestibility of the six experimental diets in duplicates. Seven fish with an average weight of $35 \mathrm{~g}$ were stocked in each aquarium and fed on at $2 \%$ of body weight for 30 days. Faeces were collected by syphone technique. Faeces were pooled and dried in an oven at $80-60^{\circ} \mathrm{C}$ overnight. Acid insoluble ash (silica) was determined in feed and faeces to be used as indigenous indicator to determine digestion coefficient of diets using the following equation according to Hepher (1988):

Apparent digestibility coefficient $\%=$

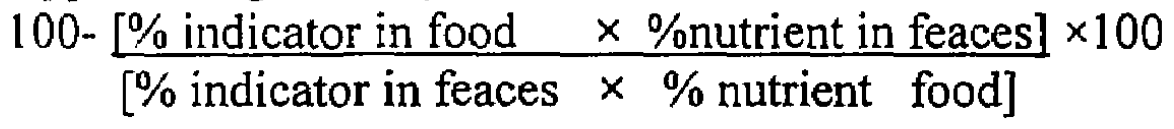

\section{Triiodothyronine}

At the end of experiment, blood was sampled from 2 fish from each aquarium of the experimental treatments from the heart (after fish were fed on on the experimental diets) and the blood was centrifuged to obtain serum. Serum thyroid hormone level was analyzed by solid phase radioimmunoassay (RIA) using commercial Kit obtained from Immunotech S.A.S. (Marseille Cedex - France).

\section{Economical evaluation}

The cost of feed required to produce one kilogram of body weight gain was calculated based on the current prices of feed ingredient of diets and feed conversion ratio.

Feed cost $/ \mathrm{Kg}$ of fish $=$ feed conversion ratio $\times$ cost per $\mathrm{Kg}$ of feed Statistical analysis

The results of the experiment were statistically analyzed in two way manner, using a computer software application of MSTAT version 4 
Osama M. El-Husseiny et al.

(1987) program. Duncan's new multiple range test was conducted to determine the significant differences between data generated (Duncan, 1955).

\section{RESULTS \\ Tilapia Growth and Feed utilization}

The growth performance and feed utilization of Nile tilapia fed on on four mixed protein schedules and $\mathrm{Three} \mathrm{Na} / \mathrm{K}$ ratios are presented in Table(3)

Regarding to mixed protein schedules, the highest fish performance was noticed with fish fed on $(5 \mathrm{~A} / 1 \mathrm{~B})$ schedule. No significant difference was observed between fish fed on (6A) and (4A/2B) schedules. The best feed conversion ratio was listed for $(6 \mathrm{~A})$ without significant differences with $(5 \mathrm{~A} / 1 \mathrm{~B})$. The highest protein efficiency ratio (PER) was recorded in $(5 \mathrm{~A} / 1 \mathrm{~B})$ without significant differences between $(6 \mathrm{~A})$ and $(4 \mathrm{~A} / 2 \mathrm{~B})$. The highest protein productive value (PPV \%) was recorded with fish fed on $(5 \mathrm{~A} / 1 \mathrm{~B})$ schedule, while fish in $(6 \mathrm{~A})$ recorded the highest energy retention(ER).

Concerning the effect of $\mathrm{Na} / \mathrm{K}$ ratios, the best growth performance and feed utilization were recorded for fish fed on on diets with $\mathrm{Na} / \mathrm{K}$ ratio $2\left(R_{2}\right)$ except for feed consumption. However, the least values of these parameters were shown for fish fed on on diets with $\mathrm{Na} / \mathrm{K}$ ratio $1.5\left(R_{1.5}\right)$ except for energy retention, which increased with increasing $\mathrm{Na} / \mathrm{K}$ ratio (Fig.2).

The interaction between $\mathrm{Na} / \mathrm{K}$ ratio and mixed protein schedules recorded an improvement in the final body weight and average body weight gain for fish fed on (3A/3B) R2 schedule in comparison with fish fed on $(3 \mathrm{~A} / 3 \mathrm{~B}) \mathrm{R} 0.5$ and $(3 \mathrm{~A} / 3 \mathrm{~B}) \mathrm{R} 1.5$ schedules. No significant difference was observed between fish fed on $(3 A / 3 B) R_{2}$ and fish fed on $(6 \mathrm{~A}) R_{0.5}$ schedules .The best feed conversion ratio, protein efficiency ratio, protein productive value and energy retention were recorded for fish fed on $(4 \mathrm{~A} / 2 \mathrm{~B}) \mathrm{R}_{2}$ schedule.

\section{The Whole Body Chemical Composition}

The chemical composition of tilapia whole body is presented in Table (4).With regard to mixed protein schedule, the highest percentage of dry matter, crude protein and ether extract were $24.98,59.99$ and 16.66 for fish fed on $(6 \mathrm{~A}),(5 \mathrm{~A} / 1 \mathrm{~B}),(6 \mathrm{~A})$ schedules respectively .The ether extract content decreased at high inclusions rate of lower protein diet in mixed protein schedules $(4 \mathrm{~A} / 2 \mathrm{~B})$ and $(3 \mathrm{~A} / 3 \mathrm{~B})$. The highest ash content was observed with $(5 \mathrm{~A} / 1 \mathrm{~B})$. 
Regarding the effect of $\mathrm{Na} / \mathrm{K}$ ratio, the highest percentages of dry matter and ether extract was recognized for fish fed on diets with $\mathrm{Na} / \mathrm{K}$ ratio $2\left(R_{2}\right)$. Meanwhile, the highest protein and ash percentages were obtained by fish fed on diets with $\mathrm{Na} / \mathrm{K}$ ratio $0.5\left(\mathrm{R}_{0.5}\right)$. Crude protein and ash contents tended to decrease linearly with increasing dietary $\mathrm{Na} / \mathrm{K}$ ratio, while dry matter and ether extract contents showed the opposite trend. Sodium content of fish carcass( Fig.3.) increased significantly with raising diets $\mathrm{Na} / \mathrm{K}$ ratio up tol.5( $\left.\mathrm{R}_{1.5}\right)$ and keep stability in sodium content with raising ratio up to $\mathrm{Na} / \mathrm{K}$ ratio2 $\left(\mathrm{R}_{2}\right)$. while, the highest potassium content (Fig.3.) was recorded for fish fed on diets with $\mathrm{Na} / \mathrm{K}$ ratio $1.5\left(\mathrm{R}_{1.5}\right)$. Meanwhile, $\mathrm{Na} / \mathrm{K}$ ratio of fish carcass (Fig.3.) had ranged between $0.35,0.40,0.44$ for $\left(R_{0.5}\right),\left(R_{1.5}\right)$ and $\left(R_{2}\right)$. respectively .

According to the interaction between the effect of dietary $\mathrm{Na} / \mathrm{K}$ ratios and mixed protein schedules, fish fed on (5A/1B) $\mathrm{R} 0.5$ schedule showed the highest percentage of crude protein and ash contents, while the highest dry matter was recorded for fish fed on (5A/1B) R2 schedule The highest ether extract percentage recorded for fish fed on $(4 \mathrm{~A} / 2 \mathrm{~B}) \mathrm{R}_{1.5}$ schedule.

Activity of Amylase and Lipase

Lipase and amylase enzymes activity as affected by dietary $\mathrm{Na} / \mathrm{K}$ ratios are presented in Table (5). An increase in enzymes activity was observed with the elevation of $\mathrm{Na} / \mathrm{K}$ ratio, amylase showed the highest activity with $\mathrm{Na} / \mathrm{K}$ ratio $2\left(\mathrm{R}_{2}\right)$, while the highest lipase activity was noticed with $\mathrm{Na} / \mathrm{K} 1.5\left(\mathrm{R}_{1.5}\right)$. At high inclusion level of sodium chloride into fish diets ( $\mathrm{Na} / \mathrm{K}$ ratio $2\left(\mathrm{R}_{2}\right)$ ), lipase activity decreased.

\section{Digestibility Coefficient of Nutrients:}

The response of digestibility coefficients of crude protein and ether extract to $\mathrm{Na} / \mathrm{K}$ ratios are presented in Table (6).The highest value of protein digestibility was listed when fish were fed on diets with $\mathrm{Na} / \mathrm{K}$ $2\left(R_{2}\right)$. However, the best ether extract digestibility was recorded when the diet has the ratio of $\mathrm{Na} / \mathrm{K} \quad 1.5\left(\mathrm{R}_{1.5}\right)$ and the least was observed with $\mathrm{Na} / \mathrm{K} 2\left(\mathrm{R}_{2}\right)$.

\section{Triiodothyronine $\left(\mathrm{T}_{3}\right)$}

Serum level of thyroid hormone in male and female are presented in Table (7). Increasing $\mathrm{Na} / \mathrm{K}$ ratio in the diet decreased thyroid hormorie level in the male, in contrast with the females which showed an increase in thyroid hormone level with increasing $\mathrm{Na} / \mathrm{K}$ ratio. 
Osama M. El-Husseiny et al̆.

\section{Economical evaluation}

Data of economical evaluation of tested rations are summarized in Table (8) show that the lowest feed cost to produce one kilogram of fish is recorded for $(4 A / 2 B) R_{2}$.

\section{DISCUSSION}

The best growth performance and feed utilization of Nile tilapia was observed in fish fed on (5A/1B) schedule except for energy retention. Meanwhile, no significant differences were observed between fish fed on $(6 \mathrm{~A})$ and $(4 \mathrm{~A} / 2 \mathrm{~B})$ schedules. This may suggest that fish performance were not affected with more inclusion of lower protein $\operatorname{diet}(B ; 24 \%)$ in mixed protein schedules $(5 \mathrm{~A} / 1 \mathrm{~B})$ and $(4 \mathrm{~A} / 2 \mathrm{~B})$. These results are in agreement with the finding of Ali et al. (2005), who suggested that farmers can use a mixed protein schedule using alternate day feeding of high protein and low protein as a means of reducing feed cost. De Silva (1985) demonstrated that mixed protein schedules, where a high protein was alternated with a low protein, were more efficient in terms of growth and nutrient utilization compared with feeding Nile tilapia on a high protein diet continuously.

Reducing the level of dietary protein to the minimum required level for fish is critical in commercial aquaculture, since excess portion of dietary protein is wasted as ammonia via gills, which is environmentally destructive (Sugiura and Hardy, 2000). It was reported that mixed protein schedules using diets containing low and high protein increased and decreased $\mathrm{N}$ retention and loss, respectively, in tilapia and carps (De Silva, 1985; Nandeesha et al., 2002; Ali et al., 2005). The present results are in agreement with the above finding; fish fed on $(5 \mathrm{~A} / 1 \mathrm{~B})$ and $(4 A / 2 B)$ schedules utilized protein more efficiently and retained more protein than fish fed on higher protein diet continuously (6A) but by increasing days that fish fed on lower protein $\operatorname{diet}(3 \mathrm{~A} / 3 \mathrm{~B})$, protein retention decreased. Meanwhile, carcass lipid content decreased with more inclusion of lower protein diet in mixed protein schedules, which agreed with the finding of Ali et al. (2005) who reported that lipid level was higher in either catfish or silver carp muscle fed on the high protein diet continuously, while there was low fat accumulation in fish receiving low protein diet throughout. Sevgili et al. (2006) suggested that feeding rainbow trout continuously on low protein diet, resulted in significantly higher moister and lower fat levels than feeding 
continuously high protein diets. A similar finding was reported with common carp (Nandeesha et al., 2002).

Tilapia performance varied with changing dietary $\mathrm{Na} / \mathrm{K}$ ratio, performance did not follow a linear trend with increasing dietary $\mathrm{Na} / \mathrm{K}$ ratio, a drop was observed when dietary $\mathrm{Na} / \mathrm{K}$ reached $1.5\left(\mathrm{R}_{1.5}\right)$. The highest growth performance and feed utilization was recorded for $\mathrm{Na} / \mathrm{K}$ $2\left(R_{2}\right)$ followed by $\mathrm{Na} / \mathrm{K} 0.5\left(R_{0.5}\right)$, then the highest fat deposition was noticed with $\left(R_{2}\right)$. This may indicate that in lower dietary $\mathrm{Na} / \mathrm{K}$ ratio $0.5\left(R_{0.5}\right)$ more energy was required to maintain mineral balance and homeostasis by uptake needed $\mathrm{Na}^{+}$from the surrounding water which can explain the low nutrient utilization and low energy deposition (Fig.4). The present results are in agreement with the finding of $\mathrm{Li}$ et al.(2001) who reported that $\mathrm{Na} / \mathrm{K}$ ratios 1.5 and 2.5 produced the best growth in African catfish, feed efficiency was improved and consequently more fat was deposited, while low growth performance and nutrient utilization were recorded in the low $\mathrm{Na} / \mathrm{K}$ ratio group which suggest that fish consumed energy to maintain mineral balance. Smith et al. (1995) reported that freshwater rainbow trout (Oncorhynchus mykiss) fed on salt-enriched diets $(2.1 \% ; 12 \%)$ showed a suppression in branchial $\mathrm{Na}^{+}$influx from water (active transport) compared with unfed on fish, while branchial $\mathrm{Na}^{+}$efflux to water (diffusion) was only shown at higher salt loads $(12 \%) . \mathrm{Na} / \mathrm{K}$ ratio in the fish carcass in $\left(R_{0.5}\right),\left(R_{1.5}\right)$ and $\left(R_{2}\right)$ ranged around 0.4 (Fig.3), which imply that fish tried to strict homeostasis between sodium and potassium.

The previous results also agreed with those obtained by Keshavanath et al. (2003) who proved the beneficial effect of dietary inclusion of $\mathrm{NaCl}$ and suggested that response to addition of $\mathrm{NaCl}$ to fish diets depend on fish species and $\mathrm{NaCl}$ level Fontainhas-Fernandes et al.(2000) indicated that dietary supplementation with $8 \% \mathrm{NaCl}$ improved growth performance of male and female tilapia fish fed on diet for 30 days. Gangadhara et al.(2004) reported that Rohu (Labeo rohita) fish recorded significantly better feed conversion ratio (FCR), protein efficiency ratio(PER) percentage net protein retention (NPR) with increased dietary salt content compared to the other treatments.

Fish fed on dietary $\mathrm{Na} / \mathrm{K}$ ratio $1.5\left(\mathrm{R}_{1.5}\right)$ showed the highest potassium and sodium content (Fig.4). Low growth performance illustrated in this group could be explained according to the finding of Smith et al. (1995) who suggested that with increasing dietary $\mathrm{NaCl}$ $\operatorname{load}(2.1 \% ; 12 \%)$, an increase in blood $\mathrm{Na}^{+}$concentration was noticed 
Osama M. El-Husseiny et al.

and a redirection of $\mathrm{Na}^{+}$into the body tissue occurred meanwhile, diffusion of branchial $\mathrm{Na}^{+}$to water was noticed at higher load of $\mathrm{NaCl}$ only $(12 \%)$. Diets with $N a / K$ ratio $1.5\left(R_{1.5}\right)$ may resulted in high concentration of $\mathrm{Na}^{+}$in blood with low branchial $\mathrm{Na}^{+}$efflux to water , that directed fish to maintain stability of $\mathrm{Na} / \mathrm{K}$ ratio by uptake of potassium from water which encourage fish to consume more energy and led to decrease in fish performance.

Fish fed on diets with $\mathrm{Na} / \mathrm{K} 1.5\left(\mathrm{R}_{1.5}\right)$ had the highest lipase activity, with more inclusion of sodium chloride to fish diets to elevate dietary $\mathrm{Na} / \mathrm{K}$ ratio up to $2\left(\mathrm{R}_{2}\right)$, lipase activity decrease. These results explained the high ether extract digestibility coefficient for fish fed on $\mathrm{Na} / \mathrm{K} 1.5$ $\left(R_{1.5}\right)$.The same results are suggested by Keshavanath et al.(2003) who reported that salt incorporated diets caused an increase of digestive enzyme activity coupled with higher nutrient digestibility and that may have been responsible for better utilization of nutrients. De Silva and Aderson (1995) suggested that the type of diet is known to influence the activity of digestive enzymes.

Raising $\mathrm{Na} / \mathrm{K}$ ratio decreased thyroid hormone level in the male, in contras! with the females which showed an increase in thyroid hormone level with increasing $\mathrm{Na} / \mathrm{K}$ ratio. The same results were reported by Fontainhas-Fernandes et al. (2000) that female cultivated in brackish water showed an increase in growth rate which was accompanied by high plasma thyroid hormone level, while the males did not exhibit the same relationship. Males showed lower thyroid hormone level in brackish water than fresh water, which suggested that fish showed an increased requirement of thyroid hormone with increasing salinity and elevated thyroid hormone levels of females, as compared to the males, and are possibly related with the female reproductive activity. Lebel and leluop (1990) reported that transefer of eel Auguilla anguilla or brown trout Salmo trutta from fresh water to sea water involves an increase of deiodination of $T_{4}$ to $T_{3}$ sugessting an increased requirement for $T_{3}$ in sea water.

The optimal mixed protein schedule for tilapia was either (5A/1B) or $(4 \mathrm{~A} / 2 \mathrm{~B})$. Inclusion of sodium chloride to such diets to achieve $\mathrm{Na} / \mathrm{k}$ ratio 2 was beneficial and improved fish performance with decreasing inclusion of higher protein diet in protein schedules $(3 A / 3 B) R_{2}$ with no significant differences noticed in comparison with fish fed on diet with higher protein continuously $(6 \mathrm{~A}) \mathrm{R}_{0.5}$ and $(6 \mathrm{~A}) \mathrm{R}_{1.5}$ that could be 
explained as adding sodium chloride to fish diet to reach $\mathrm{Na} / \mathrm{K}$ ratio 2 helped fish to improve protein utilization.

\section{CONCLUSION}

Generally, Nile tilapia growth performance were not affected with more inclusion of lower protein diet content $(B ; 24 \%)$ in mixed protein schedule $(5 \mathrm{~A} / 1 \mathrm{~B})$ or $(4 \mathrm{~A} / 2 \mathrm{~B})$. Inclusion of sodium chloride to fish diet. to achieve $\mathrm{Na} / \mathrm{k}$ ratio2, improved fish performance. Increased $\mathrm{Na} / \mathrm{k}$ ratio affected amylase and lipase activity and thyroid hormone level in fish blood serum, the interaction between mixed protein schedule and $\mathrm{Na} / \mathrm{K}$ improved fish performance with decreasing inclusion of higher protein diets in mixed protein schedules $(3 \mathrm{~A} / 3 \mathrm{~B}) \mathrm{R}_{2}$, elevate $\mathrm{Na} / \mathrm{k}$ ratio up to 2 helped fish to utilize low protein diet efficiently. Further studies are needed to examine other $\mathrm{Na} / \mathrm{K}$ ratios for more understanding the relationship between sodium and potassium to determine the optimal $\mathrm{Na} / \mathrm{K}$ ratio in tilapia diet .

\section{REFERENCES}

Ali, M. Z.; Hossain, M. A. and Mazid, M. A.(2005). Effect of mixed feeding schedules with varying dietary protein levels on the growth of sutchi catfish, Pangasius hypophthalmus (Sauvage) with silver carp, Hypophthalmichthys molitrix (Valenciennes) in ponds. Aquacult. Res., 36: 627-634.

Abdelghany, A. E. (2000). Replacement value of cystine for methionine in semi-purified diets supplemented with free amino acids for the Nile Tilapia (Oreochromis niloticus)L.fry. Proceeding from the Fifth International Symposium on Tilapia Aquaculture, Rio de Janeiro - RJ, Brazil, I: 109-119.

AOAC (1990). Association of Official Analytical Chemists. Official Methods of Analysis of the Association of Official Analytical Chemists, 15 th edition. Association of Official.

Avault, J. W. (1996). Foundamentals of Aquaculture. AVA Publishing Company Inc.,Baton ,Rouge, Louisiana. 
Bernfeld, P. (1955).Amylases a e $\beta$ : colorimetric assay method. In: Methods in Enzymology. Ed. Colowich,'S.P. \& Kaplan, N.O., Vol. 1. New York: Academic Press Inc.

De Silva, S.S. (1985) Performance of $O$. niloticus (L) fry maintained on mixed feeding schedules of differing protein content. Aquacult. and Fish. Manag., 6:331-340.

De Silva. S.S. and Aderson, T.A. (1995). Fish Nutrition in Aquaculture. Chapman \& Hall. London. 319 pp.

Dersjant-Li, Y.; Wua, S.; Verstegen, M. W.A.; Schrama, J.W. and Verreth, J.A.J.(2001) The impact of changing dietary NarK ratios on growth and nutrient utilisation in juvenile African catfish, Clarias gariepinus. Aquacult., 198:293-305.

Duncan, D.B. (1955).Multiple range and multiple $F$ tests .Biometrics $11: 1-42$

FAO (2003). Culture species Cultured Aquatic Species Information Programme Oreochromis niloticus (1). http://www.fao.org

Fontainhas-Fernandes, A.; Monteiro, M.; Gomes, E.; Reis-Henriques, M. and Coimbra, J.(2000). Effect of dietary sodium chloride acclimation on growth and plasma thyroid hormones in tilapia Oreochromis niloticus (L.) in relation to sex. Aquacult. Res., $31: 507-512$

Gangadhara, B.; Nandeesha, M. C.; Keshavanath, P. and Varghese, T. J.(2004). Growth Response and Biochemical Composition of Rohu, Labeo rohita, Fed on Salt Incorporated Diets. J. Appl. Aquacult., $16(1 / 2): 169-176$

Grewal, R. and Mahmood, A. (2004). Coordinate secretion of alkaline phosphatase into serume and intestine in fat-fed on rats. Indian J. Gastroenterol. 23: 175-177.

Harpaz, S.; Hakim, Y.; Slosman, T. and Eroldogan, O.T. (2005a). Effects of adding salt to the diet of Asian sea bass Lates calcarifer reared in fresh or salt water recirculating tanks, on 
growth and brush border enzyme activity. Aquacult. 248: 315324.

Harpaz, S.; Hakim, Y.; Barki, A.; Karplus, I.; Slosman, T. and Eroldogan, O.T.(2005b). Effects of different feeding levels during day and/or night on growth and brush-border enzyme activity in juvenile Lates calcarifer reared in freshwater recirculating tanks. Aquacult., 248: 325-335.

Hashim, R. (1994). The effect of mixed feeding schedules of varying dietary protein content on the growth performance of Chamna striata fry. Asian Fish. Sci., 7,149-155.

Hepher, B.; Liao, I.C.; Cheng, S.H. and Haseih , C.S. (1983). Food utilization by red tilapia. Effect of diet composition, feeding level and temperature on utilization efficiency for maintenance and growth .Aquacult., 32:255-272.

Hepher, B. (1988) Nutrition of pond fish .Cambridge Univ.press

Johnson A. (2007) Salt or Oxygen ?,Given this choice, what's best for taking stress out of fish? http://www.oxyedgechum.com/oxygen or salt.htm.

Keshavanath, P.; Gangadhara, B. and Khadri, S.(2003).Growth enhancement of carp and prawn through dietary sodium chloride supplementation. Aquacult. Asia, 8(4):4-8

Laiz-Carrion, R.; Sangiao-Alvarellos, S.; Guzman, J.M.; Martin M.P.; Miguez, J.M.; Soengas J.L. and Mancera J.M. (2002)Energ: metabolism in fish tissues related to osmoregulation and cortisol action: Fish growth and metabolism. Environmental. nutritional and hormonal regulation. Fish Physiol and Biochem, 27(3-4):179-188.

Lebel J.M. and Leloup J.(1990) Function thyroidenne au cours de la smotification et de l'adaptation a l'au de mer chez la salmonides .Abstract Collection Bases Biologiques Aquatic. Guidel . 
Li, Y.D.; Sheng, W.; Martin, W.A.; Verstegen, B.; Johan, W. S., and Johan, A.J.V. (2001). The impact of changing dietary NarK ratios ongrowth and nutrient utilisation in juvenile African catfish, Clarias gariepinus . Aquacult., 198: 293-305

Mccormick S. D.(2001). Endocrine Control of Osmoregulation in Teleost Fish . Amer. Zool., 41:781-794

Mia, A.S.; Koger, H.D. and Tierney, M.M. (1978). Serum values of amylase and pancreatic lipase in healthy mature dogs and dogs with experimental pancreatitis. Amer. J. Vet. Res.,39: 965969.

MSTAT Version 4 (1987). Software programmer for the design and analysis of agronomic research experiments. Michigan St. Uni., M. S., USA

Nandeesha, M.C.; De Silva, S.S.; Krishnamurthy, D. and DathatriK. (1994). Use of mixed feeding schedules in fish culture .Aquacult. and Fish. Manag., 25:659-670.

Nandeesha, M.C.; De Silva, S.S. and Krishnamurthy, D. (1995). Use of mixed feeding schedules in fish culture performance of common carp, Cyprinus carpio L., on plant and animal protein based diets. Aquacult. Res. 26:161-166.

Nandeesha, M.C.; Gangadhara, B. and Manissery, J.K. (2002). Further studies on the use of mixed feeding schedules with plant- and animal-based diets for common carp Cyprinus carpio (Linnaeus). Aquacult. Res., 33: 1157-1162

NRC (National Research Council), (1993). Nutrient requirements of fish. National Academy Press, Washington, D. C.

Peter, M. S.; Lock R. C. and Bonga. S. W. (2000). Evidence for an osmoregulatory role of thyroid hormones in the freshwater mozambique tilapia Oreochromis mossambicus. Gen. Comp. Endocrinol., 120:157-167.

Santiago, C. B., (1985)Amino acid requirement of Nile Tilapia Ph.D. Diss., Auburn University, Auburn A1. 
Saha, A.K. and Ray, A.K. (1998). Performance of Labeo rohita (Ham.) fingerlings with alternate feeding of low and high protein diets. In: Technological Advancements in Fisheries (ed. by B.M. Kurup), pp.114-119. CUSAT, Cochin, India.

Sehagal, H.S. and Toor, H.S. (1991). Comparison of feeding strategies based on biomass and biomass- pond interactions. In: Fish Nutr. Res. Asia (ed. by S.S. De Silva), pp. 181-192. Asian Fisheries Society, Manila, Philippines.

Sevgili, H.; Emre, Y.; Kanyilmaz, M.; Diler, I. and Hossu, B. (2006). Effects of mixed feeding schedules on growth performance, body composition, and nitrogen-and phosphorus balance in rainbow trout, Oncorhynchus mykiss Acta ichthyologica Etpiscatoria, $36(1): 49.55$

Shiau, S.Y. and Lu, L.S. (2004). Dietary sodium requirement determined for juvenile hybrid tilapia (Oreochromis niloticus $\times 0$. aureus) reared in fresh water and seawater British J. Nutr., 91:585 -590

Siddiqui, A.Q.; Howlader, M. S. and Adam, E. B. (1988). Effects of dietary proteinlevels on growth, feed conversion and protein utilization in fry and young NileTilapia, Oreochromis niloticus. Aquacult., 70:63-73.

Smith, N. F.; Eddy, F. B. and Talbot, C.(1995). Effect of Dietary Salt Load on Transepithelial Na+ Exchange in Freshwater rainbow: trout (Oncorhynchus mykiss) The J. Exp. Biol. 198: 2359-2364

Sugiura S.H. and Hardy R.W. (2000). Environmentally friendly feeds. pp.299-310. In: Stickney R.R. (ed.) Encyclopedia of Aquacult. John Wiley and Sons, New York

Wang, K. W. and Takeuchi, T., (1985). Optimum protein and digestible energy levels indiets for Tilapia nilotica. Bull. Jap. Soc. Sci Fish., 51: 141-146.

Wang, K. W. and Takeuchi, T. and Watanabbe, T. (1985) Effect of protein levels on growth of Tilapia nilotica. Bull. Jap. Soc. Sci. Fish., 51: 133-140. 
Table(1) Design of the experimental treatments.

\begin{tabular}{|c|c|c|}
\hline Factor I & Factor 2 & \multirow{2}{*}{ Code } \\
\hline Mixed Protein Schedules (during 6 days) & $\mathrm{Na} / \mathrm{K}$ & \\
\hline \multirow{4}{*}{ 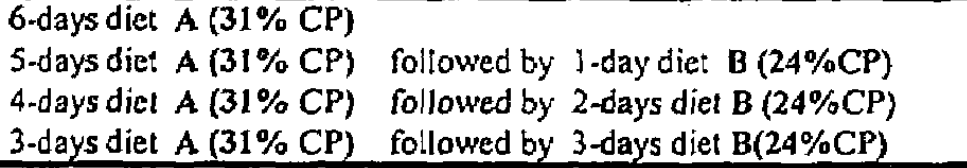 } & \multirow{4}{*}{$\begin{array}{c}\mathrm{Na} / \mathrm{K} \text { of diets } \\
\quad=0.5\end{array}$} & (6A) $R_{03}$ \\
\hline & & $(5 \mathrm{~A} / 1 \mathrm{~B}) \mathrm{R}_{0.5}$ \\
\hline & & $(4 A / 2 B) R_{0,5}$ \\
\hline & & $(3 A B B) R_{03}$ \\
\hline \multirow{4}{*}{ 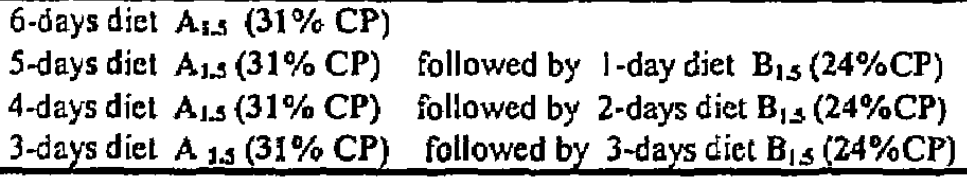 } & \multirow{4}{*}{$\begin{array}{c}\mathrm{Na} / \mathrm{K} \text { of diets } \\
\quad=1.5\end{array}$} & $(6 \mathrm{~A}) \mathbf{R}_{15}$ \\
\hline & & $(5 \mathrm{~A} / 1 \mathrm{~B}) \mathrm{R}_{\mathrm{IS}}$ \\
\hline & & $(4 A / 2 B) R_{13}$ \\
\hline & & $(3 A / 3 B) R_{15}$ \\
\hline \multirow{4}{*}{$\begin{array}{ll}\text { 6-days diet } A_{2}(31 \% C P) & \\
5 \text {-days diet } A_{2}(31 \% C P) & \text { followed by 1-day diet } B_{2}(24 \% C P) \\
\text { 4-days diet } A_{2}(31 \% C P) & \text { followed by 2-days diet } B_{2}(24 \% C P) \\
\text { 3-days diet } A_{2}(31 \% C P) & \text { followed by 3-days diet } B_{2}(24 \% C P) \\
\end{array}$} & \multirow{4}{*}{$\begin{array}{c}\mathrm{Na} / \mathrm{K} \text { of diets } \\
\quad=2\end{array}$} & $(6 \mathrm{~A}) \mathrm{R}_{2}$ \\
\hline & & $(5 A / 1 B) R_{2}$ \\
\hline & & $(4 A / 2 B) R_{2}$ \\
\hline & & $(3 A / 3 B) R_{2}$ \\
\hline
\end{tabular}

Table(2) Composition of the experimental diets

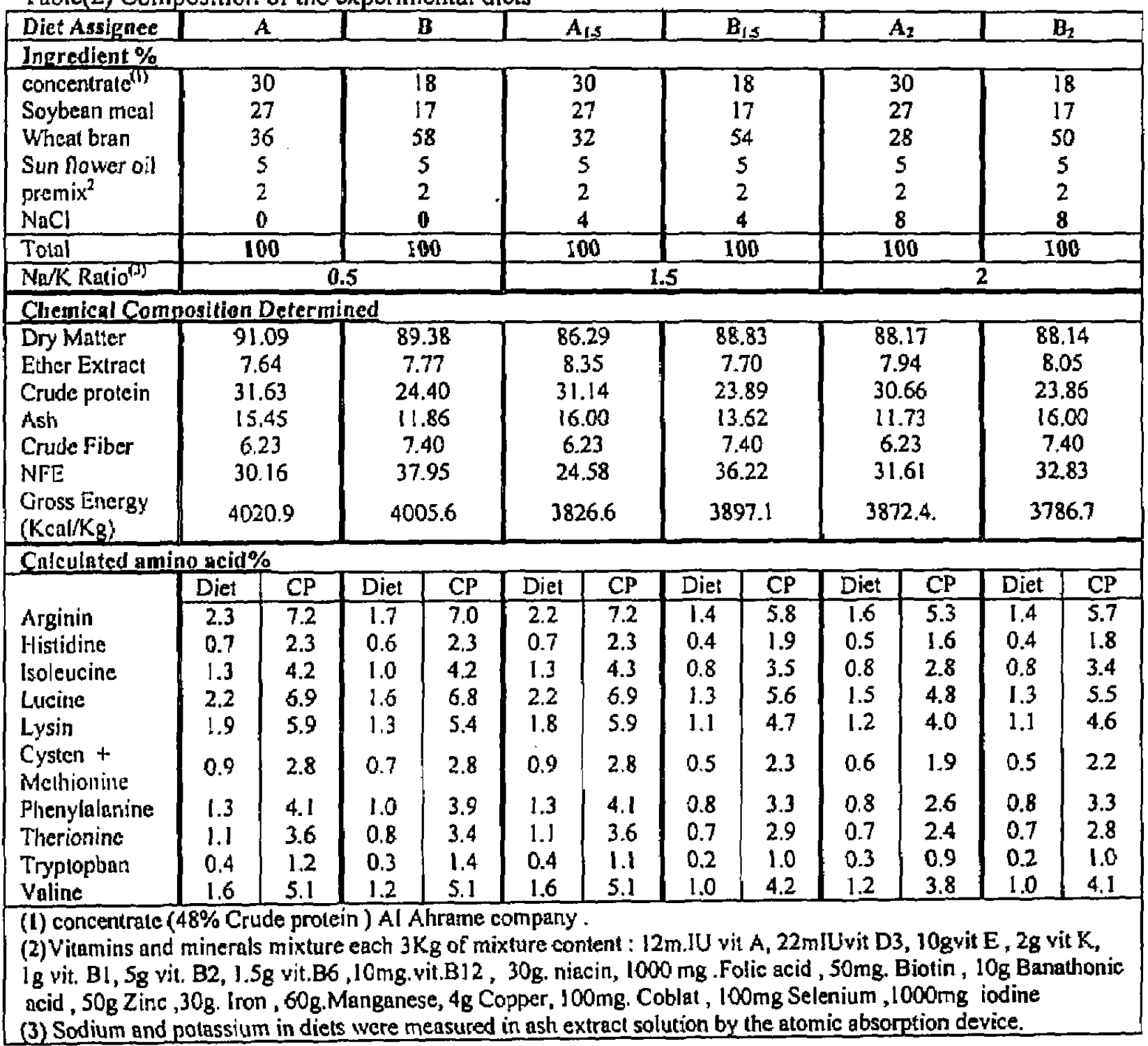


Table (3)Tilapia Performance and feed utilization in the Different Experimental Treatments.

\begin{tabular}{|c|c|c|c|c|c|c|c|c|}
\hline \multirow{2}{*}{ Criterion: } & \multicolumn{2}{|c|}{ Fish weight (g) } & \multirow{2}{*}{ ADG } & \multirow{2}{*}{$\begin{array}{c}\text { Feed } \\
\text { intake } \\
\text { g/day//ish }\end{array}$} & \multirow[b]{2}{*}{$\mathbf{F C R}^{\star}$} & \multirow[b]{2}{*}{ PER } & \multirow[b]{2}{*}{ PPV* } & \multirow[b]{2}{*}{ ER* } \\
\hline & Initial & Final & & & & & & \\
\hline \multicolumn{9}{|c|}{ Efrect of Mixed Protein Schedule } \\
\hline $6 \mathrm{~A}$ & 15.47 & $46.24^{\mathrm{s6}}$ & $0.342^{86}$ & $0.586^{6}$ & $1.717^{\mathrm{g}}$ & $1.659^{\circ}$ & $24.13^{5}$ & $15.55^{\mathrm{A}}$ \\
\hline $5 \mathrm{~A} / 1 \mathrm{~B}$ & 15.35 & $47.44^{\mathrm{a}}$ & $0.357^{\mathrm{a}}$ & $0.629^{a}$ & $1.767^{\mathrm{a}}$ & $1.679^{\mathrm{m}}$ & $25.52^{\mathrm{a}}$ & $14.5 \mathrm{~s}^{\mathrm{b}}$ \\
\hline $4 A / 2 B$ & 15.30 & $44.33^{b}$ & $0.322^{b}$ & $0.603^{\mathrm{ab}}$ & $1.888^{\mathrm{b}}$ & $1.652^{\mathrm{a}}$ & $24.83^{\mathrm{nb}}$ & $1400^{\circ}$ \\
\hline $3 A / 3 B$ & 15.52 & $34.99^{c}$ & $0.229^{c}$ & $0.540^{c}$ & $2.424^{c}$ & $1.356^{b}$ & $19.20^{\mathrm{c}}$ & $10.08^{\mathrm{d}}$ \\
\hline SEt & - & 0.874 & 0.011 & 0.011 & 0.021 & 0.018 & 0.431 & 0.158 \\
\hline \multicolumn{9}{|c|}{ Effect of $\mathrm{Na} / \mathrm{K}$ ratio } \\
\hline $\mathrm{R}=0.5$ & 15.15 & $44.23^{\mathrm{a}}$ & $0.322^{\mathrm{a}}$ & $0.617^{\mathrm{a}}$ & $1.976^{\mathrm{b}}$ & $1.576^{b}$ & $23.14^{6}$ & $12.28^{\circ}$ \\
\hline$R=1.5$ & 15.57 & $41.35^{b}$ & $0.286^{\mathrm{b}}$ & $0.561^{c}$ & $2.068^{\mathrm{c}}$ & $1.482^{\mathrm{C}}$ & $21.17^{c}$ & $12.52^{\mathrm{b}}$ \\
\hline$R=2$ & 15.52 & $45.16^{\mathrm{a}}$ & $0.329^{\mathrm{a}}$ & $0.590^{b}$ & $1.804^{\pi}$ & $1.702^{\star}$ & $25.94^{\mathrm{a}}$ & $15.86^{\circ}$ \\
\hline $\mathrm{SE}+$ & - & 0.694 & 0.009 & 0.009 & 0.018 & 0.016 & 0.373 & 0.137 \\
\hline \multicolumn{9}{|l|}{ Interaction } \\
\hline (6A) $R_{0,5}$ & 15.23 & $46.17^{\mathrm{ab}}$ & $0.344^{\mathrm{ab}}$ & $0.608^{b c}$ & $1.773^{6}$ & $1.626^{\circ}$ & $23.67^{c d}$ & $15.15^{6}$ \\
\hline$(5 \mathrm{~A} / 1 \mathrm{~B}) \mathrm{R}_{0,5}$ & 14.90 & $48.19^{\mathrm{a}}$ & $0.370^{a}$ & $0.641^{\mathrm{ab}}$ & $1.732^{\mathrm{ab}}$ & $1.732^{6}$ & $27.17^{b}$ & $12.58^{d}$ \\
\hline (4A/2B) $R_{0.5}$ & 15.28 & $47.05^{\mathrm{a}}$ & $0.353^{\mathrm{a}}$ & $0.683^{\mathrm{a}}$ & $1.935^{\mathrm{cd}}$ & $1.616^{\mathrm{c}}$ & $23.27^{\mathrm{cd}}$ & $11.65^{\circ}$ \\
\hline$(3 \mathrm{~A} / 3 \mathrm{~B}) \mathrm{R}_{0.5}$ & 15.17 & $34.85^{\mathrm{d}}$ & $0.219^{\mathrm{de}}$ & $0.537^{d e}$ & $2.462^{f}$ & $1.329^{\mathrm{c}}$ & $18.45^{f}$ & $9.750^{\prime}$ \\
\hline (6A) $R_{15}$ & 15.47 & $46.10^{\mathrm{ab}}$ & $0.340^{\mathrm{ab}}$ & $\equiv 0.587^{\text {bed }}$ & $1.725^{\mathrm{Bb}}$ & $1.607^{\mathrm{c}}$ & $21.77^{d e}$ & $13.61^{6}$ \\
\hline$(5 A / 1 B) R_{1.5}$ & 15.67 & $48.25^{\mathrm{a}}$ & $0.362^{a}$ & $0.607^{\mathrm{bc}}$ & $1.679^{\mathrm{ab}}$ & $1.724^{b}$ & $23.80^{\mathrm{cd}}$ & $15.38^{b}$ \\
\hline (4A/2B) RI.5 & 15.45 & $39.00^{\mathrm{C}}$ & $0.262^{\text {cd }}$ & $0.544^{\text {de }}$ & $2.079^{\circ}$ & $1.457^{d}$ & $20.95^{\circ}$ & $12.69^{d}$ \\
\hline$(3 A / 3 B) R_{1.5}$ & 15.68 & $32.05^{\mathrm{d}}$ & $0.182^{\circ}$ & $0.507^{e}$ & $2.789^{8}$ & $1.139^{f}$ & $18.17^{f}$ & $8.38 \%^{8}$ \\
\hline (6A) $R_{2}$ & 15.70 & $46.44^{n}$ & $0.342^{\mathrm{ab}}$ & $.0 .563^{\text {cde }}$ & $1.654^{\mathrm{a}}$ & $1.744^{6}$ & $26.94^{b}$ & $17.89^{2}$ \\
\hline$(5 \mathrm{~A} / \mathrm{B}) \mathrm{R}_{2}$ & 15.47 & $45.85^{\mathrm{ab}}$ & $0.338^{\mathrm{ab}}$ & $0.639^{\mathrm{ab}}$ & $1.890^{\mathrm{C}}$ & $1.581^{\circ}$ & $25.57^{\mathrm{bc}}$ & $15.79^{b}$ \\
\hline$(4 A / 2 B) R_{2}$ & 15.18 & $46.93^{\mathrm{a}}$ & $0.353^{\mathrm{a}}$ & $0.581^{\text {bed }}$ & $1.650^{\mathrm{g}}$ & $1.883^{\mathrm{a}}$ & $30.28^{\mathrm{a}}$ & $17.66^{2}$ \\
\hline$(3 A / 3 B) R_{2}$ & 15.71 & $41.39^{b c}$ & $0.285^{\mathrm{bc}}$ & $0.576^{\mathrm{cd}}$ & $2.021^{\text {de }}$ & $1.600^{\mathrm{c}}$ & $20.96^{\mathrm{e}}$ & $12.10^{d}$ \\
\hline $\mathrm{SE}+$ & - & 1.514 & 0.018 & 0.018 & 0.037 & 0.032 & 0.747 & 0.274 \\
\hline
\end{tabular}

$\mathrm{SE} \pm$ standard error calculated from residual mean square in the analysis of variance $a, b, \ldots$ e: $c$. means in the same column with different superscription are significantly different $(P<0.05)$

* DM basis 
Table (4) The chemical Composition of tilapia whole body in the different experimental treatments (DM basis)

\begin{tabular}{|c|c|c|c|c|}
\hline Criterion & Dry Matter \% & Crude Protein \% & Ether Extract \% & Ash \% \\
\hline \multicolumn{5}{|c|}{ Effect of Mixed Protein Schedule } \\
\hline $6 \mathrm{~A}$ & $24.98^{a}$ & $57.94^{6}$ & $16.66^{\mathrm{a}}$ & $21.19^{b}$ \\
\hline $5 A / 1 B$ & $24.94^{\mathrm{a}}$ & $59.99^{\mathrm{a}}$ & $14.97^{c}$ & $22.59^{\mathrm{a}}$ \\
\hline $4 A / 2 B$ & $24.66^{b}$ & $59.79^{\mathrm{a}}$ & $15.97^{b}$ & $21.48^{b}$ \\
\hline $3 A / 3 B$ & $24.67^{b}$ & $57.77^{b}$ & $14.50^{\circ}$ & $22.41^{\mathrm{a}}$ \\
\hline SE \pm & 0.024 & 0.467 & 0.097 & 0.235 \\
\hline \multicolumn{5}{|c|}{ Effect of $\mathrm{Na} / \mathrm{K}$ ratio } \\
\hline$R=0.5$ & $23.91^{c}$ & $60.92^{\mathrm{a}}$ & $13.88^{\circ}$ & $22.28^{\mathrm{a}}$ \\
\hline$R=1.5$ & $24.2^{b}$ & $59.13^{b}$ & $\cdot 16.07^{8}$ & $21.95^{\mathrm{ab}}$ \\
\hline$R=\mathbf{2}$ & $26.33^{\mathrm{a}}$ & $56.57^{c}$ & $16.63^{a}$ & $21.52^{b}$ \\
\hline SEI & 0.02 & 0.404 & 0.084 & 0.203 \\
\hline \multicolumn{5}{|l|}{ Interaction } \\
\hline (6A) $R_{0,5}$ & $24.53^{c}$ & $59.31^{c}$ & $17.26^{\mathrm{cd}}$ & $20.66^{d e}$ \\
\hline$(5 A / 1 B) R_{0.5}$ & $23.28^{\mathrm{h}}$ & $65.50^{\mathrm{a}}$ & $10.22^{i}$ & $23.58^{\circ}$ \\
\hline$(4 A / 2 B) R_{0.5}$ & $23.27^{h}$ & $61.72^{b}$ & $32.54^{h}$ & $22.04^{b c}$ \\
\hline$(3 A / 3 B) R_{0.5}$ & $24.57^{e}$ & $57.17^{\mathrm{cd}}$ & $15.48^{\mathrm{e}}$ & $22.83^{\mathrm{ab}}$ \\
\hline$(6 \mathrm{~A}) \mathrm{R}_{1,5}$ & $23.62^{8}$ & $58.37^{\mathrm{cd}}$ & $15.02^{\circ}$ & $22.65^{\mathrm{ab}}$ \\
\hline$(5 A / 1 B) R_{15}$ & $24.47^{\circ}$ & $57.05^{\mathrm{cd}}$ & $16.85^{d}$ & $22.10^{b c}$ \\
\hline$(4 A / 2 B) R 1.5$ & $24.47^{e}$ & $58.61^{\text {cỏ }}$ & $17.96^{\mathrm{a}}$ & $21.20^{\text {cde }}$ \\
\hline$(3 A / 3 B) R_{1.5}$ & $24,23^{f}$ & $62.46^{6}$ & $14.44^{f}$ & $21.87^{\text {bed }}$ \\
\hline (6A) $R_{2}$ & $26.80^{b}$ & $56.12^{d}$ & $17.71^{\text {abc }}$ & $20.25^{e}$ \\
\hline$(5 A / 1 B) R_{2}$ & $27.08^{3}$ & $57.42^{\mathrm{cd}}$ & $17.84^{a b}$ & $22.10^{\text {bc }}$ \\
\hline$(4 A / 2 B) R_{2}$ & $26.24^{\mathrm{c}}$ & $59.04^{\mathrm{c}}$ & $17.40^{b c}$ & $21.19^{\text {cde }}$ \\
\hline$(3 A / 3 B) R_{2}$ & $25.22^{\circ}$ & $53.69^{\circ}$ & $13.58^{8}$ & $22.54^{\mathrm{ab}}$ \\
\hline $\mathrm{SE}+$ & 0.041 & 0.809 & 0.167 & 0.407 \\
\hline
\end{tabular}

$S E \pm$ standard error calcutated from residual mean square in the analysis of variance $a, b, \ldots$ et $c$. means in the same column with different superscription are significantly different( $P<0.05)$ 
Table (5) :Response of amylase and lipase enzymes activity to the dietary Na/K ratio

\begin{tabular}{|c|c|c|}
\hline \multicolumn{1}{|c|}{ Criterion } & Amylase & Lipase \\
\hline Effect of Na/K ratio & \multicolumn{2}{|c|}{} \\
\hline $\mathrm{R}=0.5$ & $1.092^{\mathrm{b}}$ & $0.341^{\mathrm{c}}$ \\
$\mathrm{R}=1.5$ & $1.104^{\mathrm{b}}$ & $0.922^{\mathrm{a}}$ \\
$\mathrm{R}=2$ & $1.664^{\mathrm{a}}$ & $0.679^{\mathrm{b}}$ \\
$\mathrm{SE} \pm$ & 0.111 & 0.016 \\
\hline
\end{tabular}

$\mathrm{SE}^{ \pm}$standard error .calculated from residual mean square in the analysis of variance

$a, b, \ldots$ et $c$. means in the same coiumn with different superseription are significantly different $(P<0.05)$

* Specific activity of amylase defined as the amount of maltose that liberate $1 \mathrm{mmol}$ of maltose / 5 mir i'g stomach

** Specific activity of lipase was expressed in international unil (IU/ ing stomach)

Table (6) :Response of apparent digeslibility coefficient to the dietary $\mathrm{Na} / \mathrm{K}$ ratio

\begin{tabular}{|c|c|c|}
\hline Criterion & Crude Protein \% & Ether Extract \% \\
\hline Effect of Na/K ratio & $69.71^{\mathrm{b}}$ & $80.04^{\mathbf{2}}$ \\
$\mathrm{R}=0.5$ & $63.70^{\mathrm{c}}$ & $81.00^{\mathrm{a}}$ \\
$\mathrm{R}=1.5$ & $74.26^{\mathrm{a}}$ & $74.77^{\mathrm{b}}$ \\
$\mathrm{R}=2$ & $1.431^{\mathrm{a}}$ & 1.354 \\
$\mathrm{SE}+$ & & \\
\hline
\end{tabular}

$\mathrm{SE} \pm$ standard error calculated from residual mean square in the analysis of variance

$a, b$... et $c$. means in the same column with different superscription are significantly different $(P<0.05\rangle$

Table (7) Response of thyroid hormone in male and female to dielary $\mathrm{Na} / \mathrm{K}$ matio

\begin{tabular}{|l|c|c|}
\hline \multirow{2}{*}{ Criterion } & (Male) & $T_{3}$ (ng/dl) \\
\cline { 2 - 3 } & \multicolumn{2}{|c|}{ (Female) } \\
\hline Effect of Na/K ratio & 135 & 46 \\
$\mathrm{R}=0.5$ & 110 & 86 \\
$\mathrm{R}=1.5$ & 77.5 & 107 \\
$\mathrm{R}=2$ & & \\
\hline
\end{tabular}

Table (8) Economical evaluation of tested ration

\begin{tabular}{|c|c|c|c|}
\hline Criterion & $\begin{array}{c}\text { Cost / Kg feed, } \\
\text { (LE) }\end{array}$ & $\begin{array}{c}\text { Feed conversion ratio } \\
\text { (g geed as fed / g gain) }\end{array}$ & Feed cost/kg galn \\
\hline Interaction & \multicolumn{3}{|c|}{} \\
\hline$(6 \mathrm{~A}) \mathrm{R}_{0.5}$ & 2.190 & 1.941 & 4.250 \\
$(5 \mathrm{~A} / 1 \mathrm{~B}) \mathrm{R}_{0.5}$ & 2.134 & 1.907 & 4.070 \\
$(4 \mathrm{~A} / 2 \mathrm{~B}) \mathrm{R}_{0.5}$ & 2.079 & 2.137 & 4.443 \\
$(3 \mathrm{~A} / 3 \mathrm{~B}) \mathrm{R}_{0.5}$ & 2.024 & 2.716 & 5.498 \\
\hline$(6 \mathrm{~A}) \mathrm{R}_{1.5}$ & 2.192 & 2.001 & 4.385 \\
$(5 \mathrm{~A} / 1 \mathrm{~B}) \mathrm{R}_{1,5}$ & 2.136 & 1.933 & 4.128 \\
$(4 \mathrm{~A} / 2 \mathrm{~B}) \mathrm{R}_{1,5}$ & 2.081 & 2.383 & 4.959 \\
$(3 \mathrm{~A} / 3 \mathrm{~B}) \mathrm{R}_{1,5}$ & 2.026 & 3.184 & 6.452 \\
\hline$(6 \mathrm{~A}) \mathrm{R}_{2}$ & 2.194 & 1.866 & 4.993 \\
$(5 \mathrm{~A} / 1 \mathrm{~B}) \mathrm{R}_{2}$ & 2.138 & 2.145 & 4.586 \\
$(4 \mathrm{~A} / 2 \mathrm{~B}) \mathrm{R}_{2}$ & 2.083 & 1566 & 3.886 \\
$(3 \mathrm{~A} / 3 \mathrm{~B}) \mathrm{R}_{2}$ & 2.028 & 2.295 & 4.653 \\
\hline
\end{tabular}




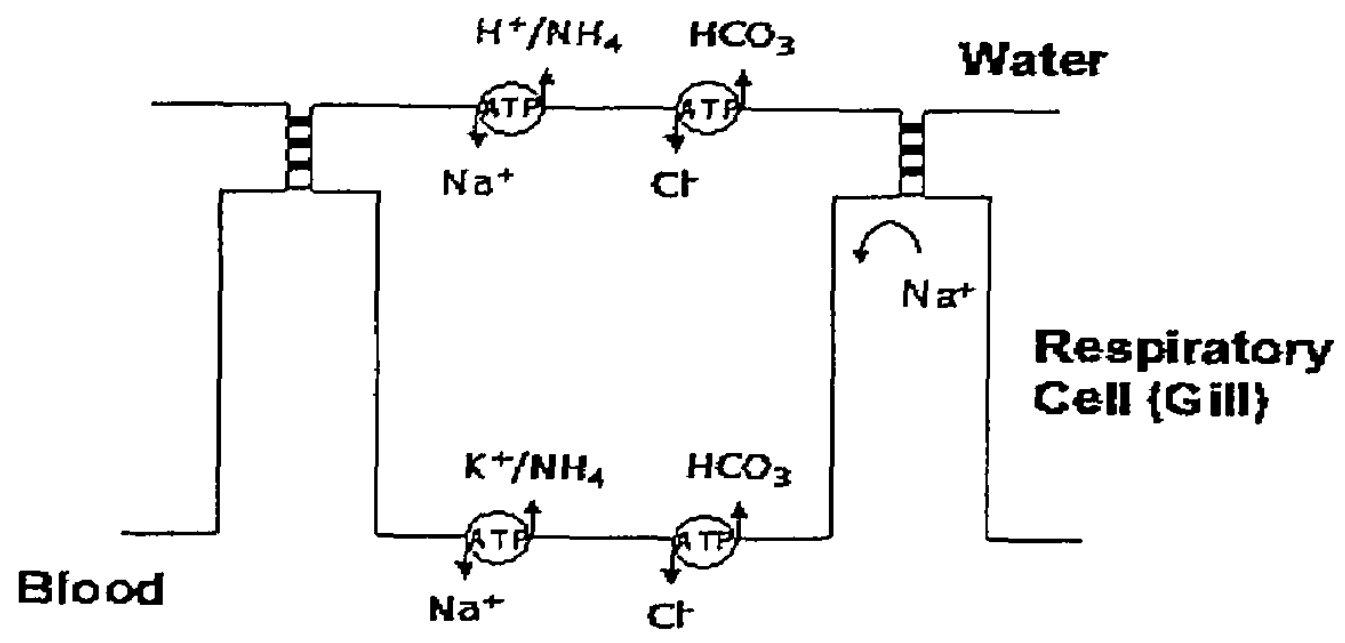

Fig.1. Model for Na-K pump and ion transportation in freshwater fish gill (Johnson, 2007)

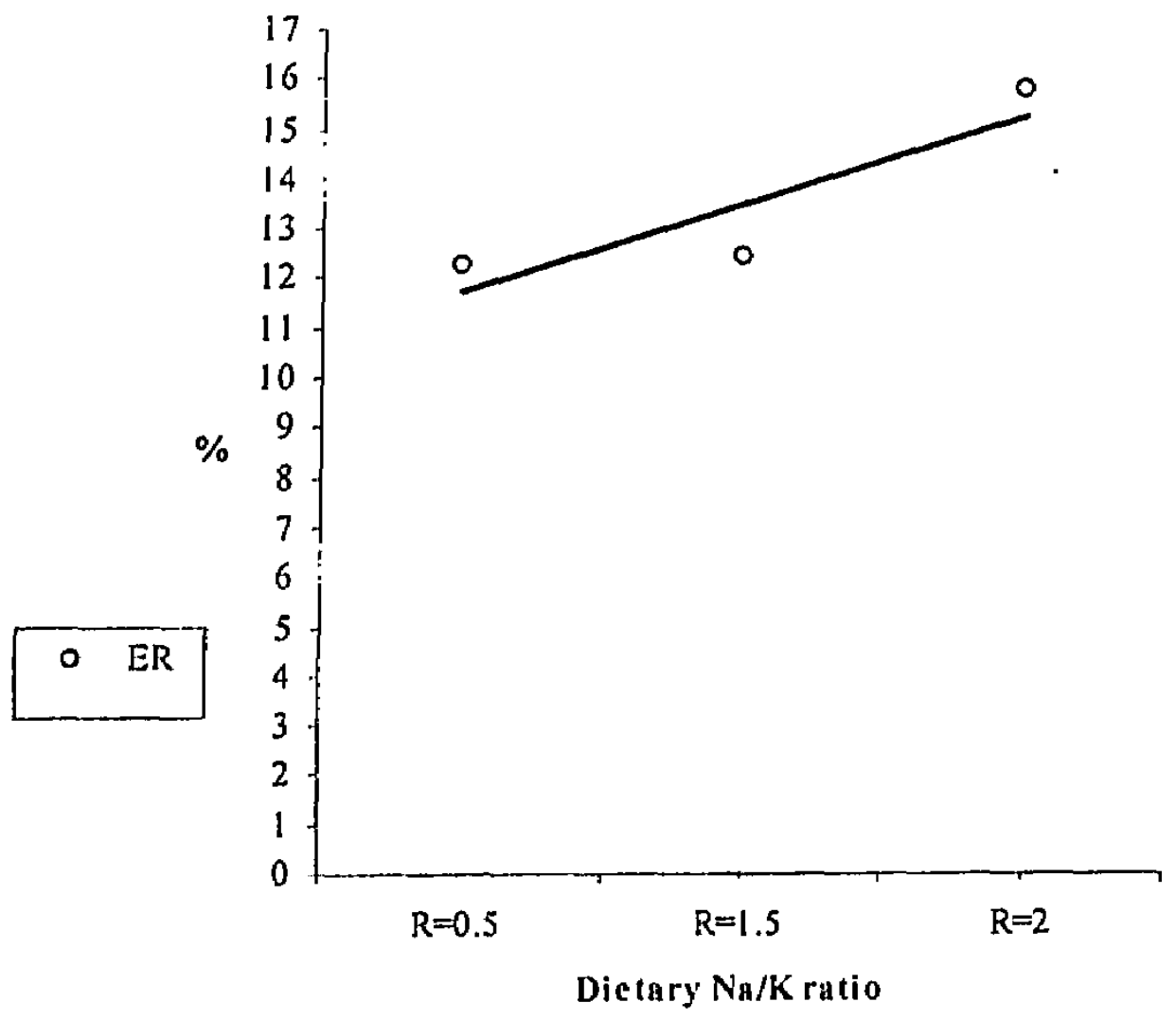

Fig.2.Effect of dietary $\mathrm{Na} / \mathrm{K}$ on Nile tilapia energy retention 


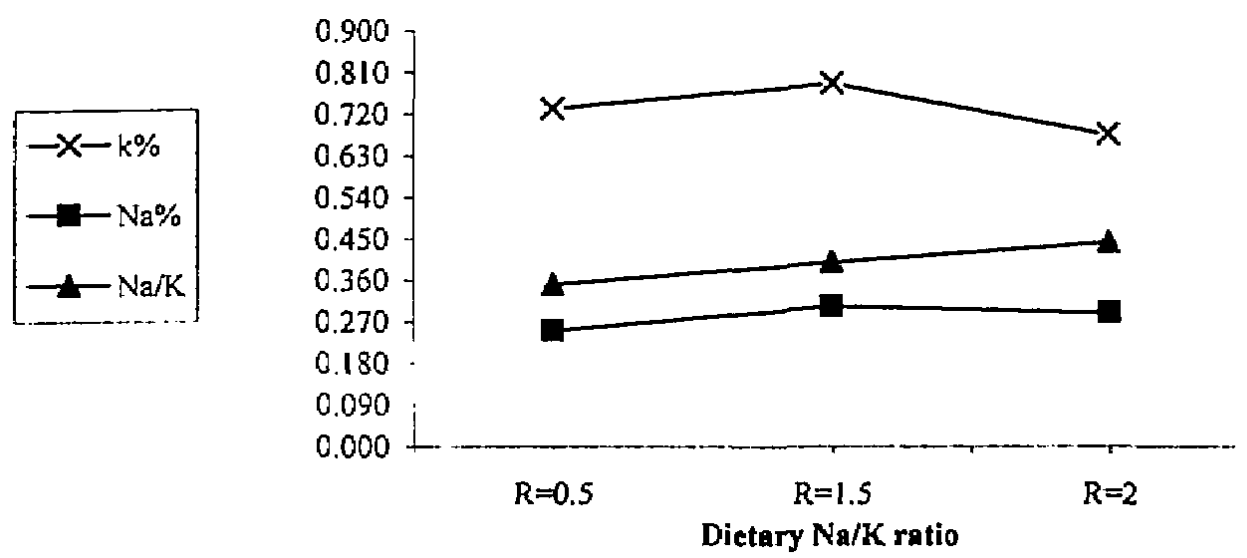

Fig. 3.Effect of dietary $\mathrm{Na} / \mathrm{K}$ ratio on potasium , sodjum and $\mathrm{Na} / \mathrm{K}$ ratio in Nile tilapia carcass

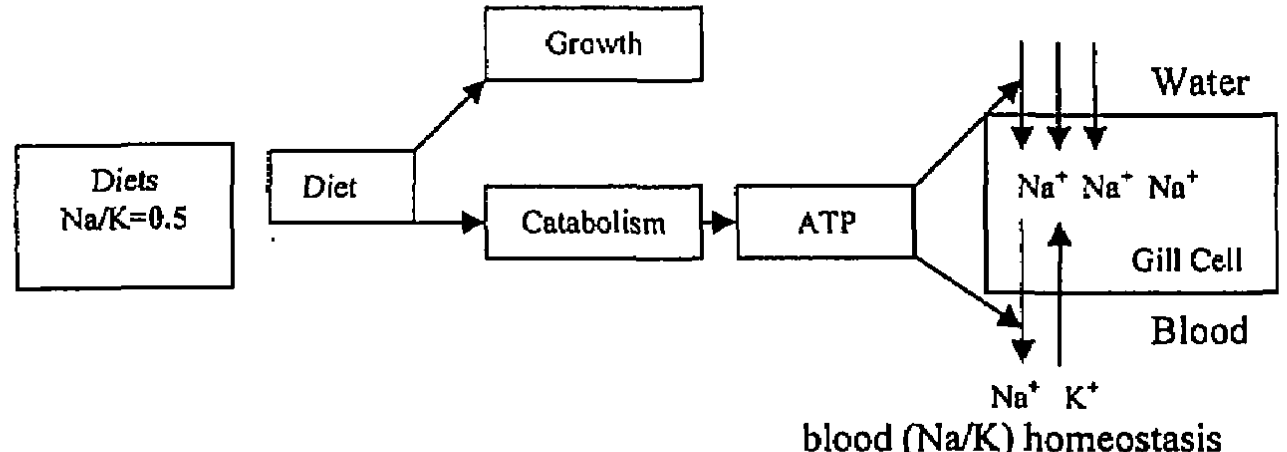

blood $(\mathrm{Na} / \mathrm{K})$ homeostasis

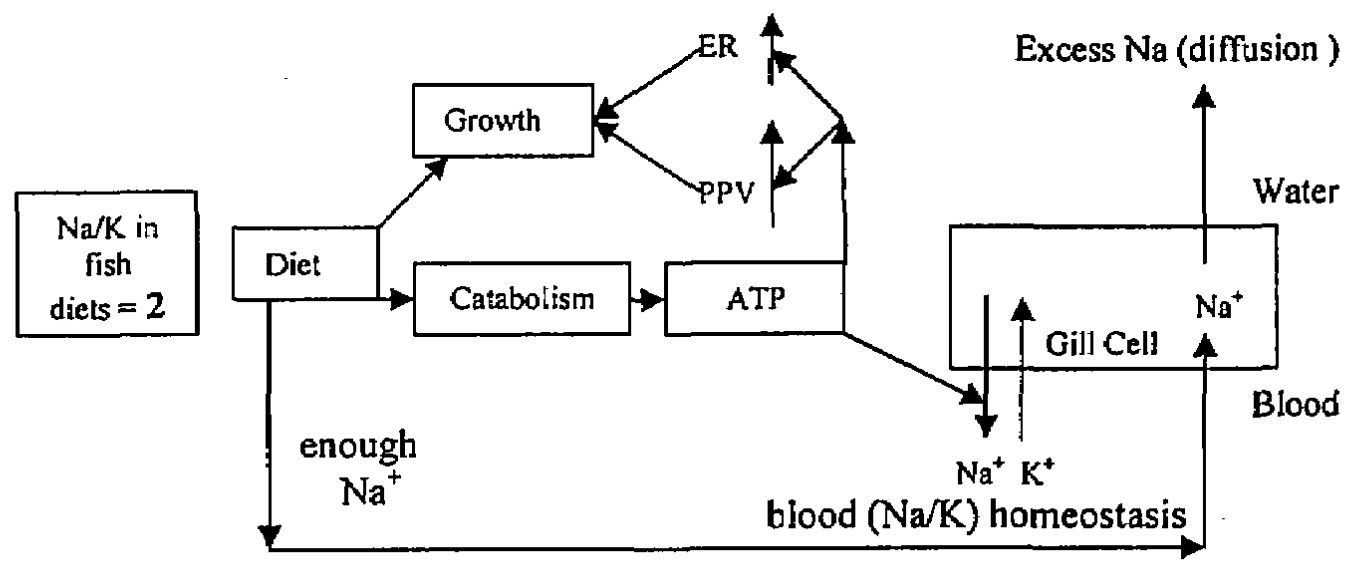

Fig.4.Model assuming the relationship between dietary $\mathrm{Na} / \mathrm{K}$ ratio, body $\mathrm{Na} / \mathrm{K}$ ratio and feed utilization 